\title{
Lupus Eritematosus Sistemik pada Pria
}

Zikry Aulia Hidayat $^{1}$, Raveinal ${ }^{2}$

1. Program Pendidikan Dokter Spesialis Ilmu Penyakit Dalam, Fakultas Kedokteran Universitas Andalas; 2. Subbagian Alergi Imunologi Bagian Ilmu Penyakit Dalam, Fakultas Kedokteran Universitas Andalas/RSUP Dr. M. Djamil Padang

Korespondensi: Zikry Aulia Hidayat; alamt e-mail: zikryaulia@gmail.com; no.ponsel:085263750109

\section{Abstrak}

Latar Belakang: Lupus eritematosus sistemik (LES) merupakan penyakit autoimun kompleks yang menyerang berbagai sistem tubuh. Insiden dan prevalensi LES tertinggi ditemukan di Amerika Utara sebesar 23,2/100.000 penduduk/tahun dan 241/100.000 penduduk. Berdasarkan jenis kelamin, LES lebih banyak didapatkan pada wanita dibandingkan pria dengan rasio 15:1 hingga 22:1. Perbedaan ini menyebabkan sering tertundanya diagnosis LES pada pasien pria. Metode: Laporan kasus. Hasil: Dilaporkan kasus laki-laki 21 tahun dengan keluhan nyeri sendi-sendi disertai bercak kehitaman di wajah, rambut rontok, sariawan, dan penurunan berat badan. Dari pemeriksaan laboratorium diperoleh peningkatan SGOT, SGPT, dan D-Dimer. Selain itu, dari ANA profile didapatkan hasil yang positif, yaitu RNP/Sm (RNP/Sm) (++), Sm (Sm) (+), Ro-52 recombinant (52) (+), PCNA (PCNA) (+), DsDNA (DNA) (+), Nucleosome (NUC) (+), Histone (HI) (++), Ribosomal-P-protein (RIB) (+++), dan AMA-M2 (M2) (+). Pasien juga memenuhi kriteria LES berdasarkan skor ACR 1997, SLICC 2012, serta EULAR/ACR 2018. Pasien diterapi dengan metilprednisolon oral 16-16-8 mg serta profilaksis VTE dengan heparin subkutan dosis $2 \times 5000$ IU. Simpulan: Penyakit LES pada pria lebih jarang prevalensinya dibandingkan wanita dengan manifestasi yang lebih beragam.

Kata kunci: Lupus eritematosus sistemik; pria; SLEDAl; MEX-SLEDAI

\section{Abstract}

Background: Systemic lupus erythematosus (SLE) is a complex autoimmune disease involving many organ systems. The highest incidence and prevalence of SLE is found in Northern America as much as $23,2 / 100,000$ population/year and 241/100,000 population. According to sex differences, SLE is predominantly occurs in women than men with ratio 15:1 to 22:1. This discrepancy often causes delay in diagnosing SLE in male patients. Method: Case report. Result: We reported a male patient aged 21 years with pain of his joints, hyperpigmentation lesions on his face, alopesia, oral ulcers, and decrease of body weight. Laboratory results showed increases in AST, ALT and D-Dimer, and from ANA profile examination we got several positives results such as RNP/Sm (RNP/Sm) (++), Sm (Sm) (+), Ro-52 recombinant (52) (+), PCNA (PCNA) (+), DsDNA (DNA) (+), Nucleosome (NUC) (+), Histone (HI) (++), Ribosomal-P-protein (RIB) (+++), and AMA-M2 (M2) (+). This patient met the SLE criteria based on ACR 1997, SLICC 2012, and EULAR/ACR 2018. Patient was given oral methyl prednisolone 16-16-8 mg and VTE prophylaxis with subcutaneous heparin $2 \times 5000$ IU. Conclusion: SLE occurs rarely in male patients than female patients and has more diverse manifestations.

Keywords: male; MEX-SLEDAl; SLEDAl; Systemic Lupus Erythematosus 


\section{PENDAHULUAN}

Lupus eritematosus sistemik (LES) merupakan penyakit inflamasi autoimun kronis yang belum jelas penyebabnya yang menyerang berbagai sistem tubuh. ${ }^{1}$ Faktor genetik dan lingkungan diketahui berperan dalam patogenesis penyakit ini. ${ }^{2}$ LES ditandai dengan pembentukan autoantibodi patogenik terhadap asam nukleat dan protein pengikatnya yang disebabkan oleh intoleransi terhadap komponen tubuh sendiri (self intolerance). Lupus eritematosus sistemik memiliki manifestasi klinis, kelainan imunologi dan laboratorium, perjalanan penyakit, serta akibat penyakit yang beragam. Manifestasi klinis pada kulit, sendi, ginjal, dan sistem organ lainnya tidak selalu muncul bersamaan, dan dapat berkembang seiring perjalanan penyakit. ${ }^{3,4}$ Insiden dan prevalensi LES tertinggi ditemukan di Amerika Utara sebesar 23,2/100.000 penduduk/tahun dan 241/100.000 penduduk. Berdasarkan jenis kelamin, LES lebih banyak ditemukan pada perempuan dibandingkan laki-laki dengan perbandingan 2:1 hingga 5:1. Data epidemiologi di Taiwan menunjukkan bahwa puncak insiden LES pada perempuan adalah dekade kedua hingga kelima. Data poliklinik di beberapa rumah sakit di Indonesia menunjukkan adanya peningkatan kunjungan pasien LES, yaitu 17,9-27,2\% (tahun 2015), 18,7-31,5\% (tahun 2016), dan 30,3-58\% (tahun 2017). Rasio perempuan dan laki-laki adalah 15:1 hingga 22:1. Awitan gejala dan tanda LES umumnya muncul pada usia 9 - 58 tahun dengan rentang usia tertinggi 21-30 tahun dan puncaknya pada usia 28 tahun. 5,6

Lupus eritematosus sistemik merupakan penyakit dengan manifestasi yang beragam dan banyak pasien yang datang dengan manifestasi klinis yang belum cukup untuk menegakkan diagnosis, sehingga penyakit ini terkadang sulit untuk didiagnosis. Seorang pasien dapat dicurigai menderita LES apabila dijumpai dua atau lebih dari kriteria, antara lain: 1) perempuan usia muda dengan keluhan atau manifestasi klinis pada dua organ atau lebih; 2) gejala konstitusional seperti kelelahan, demam tanpa bukti infeksi, penurunan berat badan; 3) muskuloskeletal yaitu artritis, artralgia, miositis; 4) kulit yaitu ruam kupu-kupu (butterfly/malar rash), fotosensitivitas, lesi membran mukosa, alopesia, fenomena Raynaud, purpura, urtikaria, vaskulitis; 5) ginjal yaitu hematuria, proteinuria, silinderuria, sindrom nefrotik; 6) gastrointestinal yaitu mual, muntah, nyeri abdomen; 7) paru yaitu kelainan pleura (pleuritis, efusi pleura), lesi parenkim paru (pneumonitis, alveolitis, bronkiektasis, penyakit interstisial paru), vaskular (hipertensi pulmonal, emboli pulmonal); 8) jantung yaitu perikarditis, endokarditis, miokarditis; 9) retikuloendotelial yaitu limfadenopati, splenomegali, hepatomegali; 10) hematologik yaitu anemia, leukopenia, limfopenia, 
trombositopenia; dan 11) neuropsikiatri yaitu kejang, psikosis, neuropati kranial dan perifer, sindrom otak organik, mielitis transversa, gangguan kognitif, sefalgia yang tidak jelas penyebabnya. ${ }^{3,6}$

Diagnosis LES ditegakkan berdasarkan gejala klinis dan pemeriksaan penunjang, serta dibantu dengan beberapa kriteria klasifikasi LES. Kriteria klasifikasi yang dapat digunakan, yaitu ACR 1997 dan SLICC 2012. Pada tahun 2018 juga telah diajukan kriteria klasifikasi baru dari EULAR/ACR yang telah divalidasi dengan sensitivitas 96,1\% dan spesifisitas 93,4\%. Kriteria ini dapat digunakan jika titer ANA-IF positif $\geq 1: 80$ atau positif dengan metode pemeriksaan lain yang ekuivalen, dan tidak ada kemungkinan penyebab selain LES. Pasien dimasukkan dalam klasifikasi LES jika memiliki skor total $\geq 10$ dengan minimal satu kriteria klinis. ${ }^{3,7}$

Penilaian aktivitas penyakit diperlukan untuk menentukan kesesuaian rencana terapi bagi setiap individu. Beberapa instrumen yang dapat digunakan, misalnya Systemic Lupus Erythematosus Disease Activity Index (SLEDAI) dan Mexican Systemic Lupus Erythematosus Disease Activity Index (MEX-SLEDAI). SLEDAI diperkenalkan pertama kali pada tahun 1985 sebagai indeks global yang menilai aktivitas penyakit LES dalam 10 hari terakhir. Skor SLEDAI dikelompokkan menjadi tanpa aktivitas penyakit (skor 0), aktivitas penyakit ringan (skor 1-5), aktivitas penyakit sedang (skor 6-10), aktivitas penyakit berat (skor 11-19), dan aktivitas penyakit sangat berat (skor >20).
Selain itu, SLEDAI juga dapat digunakan untuk menentukan luaran penyakit, yaitu kekambuhan (peningkatan skor >3), perbaikan (penurunan skor $>3$ ), persisten aktif (perubahan skor 1-3), dan remisi (skor 0). Sementara itu, MEX-SLEDAl lebih mudah diterapkan pada layanan kesehatan yang tidak memiliki fasilitas laboratorium canggih. Pengelompokan aktivitas penyakit menjadi remisi (skor 0-1), ringan (skor 2-5), sedang (6-9), berat (10-13), dan sangat berat $(\geq 14) .8,9$

LES lebih banyak menyerang wanita dibandingkan pria, di mana prevalensi LES pada pria hanya mencakup $4-18 \%$. Hal ini dapat menyebabkan tertundanya diagnosis LES pada pria karena seringkali gambaran klinis dan tanda pada pria kurang spesifik dibandingkan pada wanita. ${ }^{10}$

\section{METODE}

\section{Laporan Kasus}

\section{LAPORAN KASUS}

Seorang pasien laki-laki berusia 21 tahun dirawat di Bangsal Penyakit Dalam RSUP Dr. M. Djamil Padang dengan nyeri sendi yang dirasakan meningkat sejak 3 hari sebelum masuk rumah sakit. Nyeri sendi tersebut mulai dirasakan pasien sejak 3 bulan sebelumnya, yaitu di sendi kedua bahu, kedua lutut, kedua pergelangan kaki, hingga saat ini hampir seluruh sendi pasien dirasa nyeri. Nyeri terjadi terus-menerus dan meningkat dengan pergerakan atau aktivitas. Nyeri tidak berpindah-pindah, 
tidak disertai kaku pada pagi hari dan tidak diawali dengan riwayat trauma.

Pasien juga mengeluhkan bercak kehitaman di pipi dan hidung yang dirasa panas namun tidak gatal. Bercak tersebut awalnya berupa kemerahan yang semakin merah apabila terkena cahaya matahari. la juga merasa silau yang berlebih saat melihat cahaya matahari. Selain itu terdapat sariawan, penurunan nafsu makan, rambut yang mudah rontok, lemah letih, serta penurunan berat badan. Tidak dikeluhkan demam, perdarahan, ataupun gangguan dalam buang air kecil dan buang air besar. Riwayat alergi tidak didapatkan pada pasien maupun anggota keluarganya. Pasien belum menikah dan sehari-hari berjualan di warung. la tidak merokok ataupun memiliki kebiasaan meminum alkohol.

Pasien datang dengan keadaan umum sedang dan kesadaran composmentis cooperative, tekanan darah $110 / 70 \mathrm{mmHg}$, nadi $98 \mathrm{x} /$ menit, nafas $20 \mathrm{x} /$ menit, suhu $36,8^{\circ} \mathrm{C}$. Pasien memiliki tinggi badan 160 $\mathrm{cm}$ dan berat badan $40 \mathrm{~kg}$, dengan indeks massa tubuh $15,6 \mathrm{~kg} / \mathrm{m}^{2}$ yang tergolong underweight. Pemeriksaan fisik paru, jantung, dan abdomen didapatkan dalam batas normal. Tampak adanya malar rash pada wajah pasien, discoid rash, rambut yang mudah dicabut, dan stomatitis. Pada pemeriksaan sendi, terdapat nyeri pada sendi bahu bilateral, PIP bilateral, MTP bilateral, kedua sendi pergelangan tangan, serta kedua sendi pergelangan kaki. Range of motion pada sendi yang terkena masih bebas.

Dari hasil pemeriksaan laboratorium, didapatkan kadar hemoglobin $11 \mathrm{~g} / \mathrm{dL}$, leukosit $1.400 / \mathrm{mm}^{3}$, hematokrit 32\%, trombosit 208.000/mm $\mathrm{mm}^{3}$, LED $17 \mathrm{~mm} / \mathrm{jam}$, hitung jenis leukosit 0/0/2/44/46/8. Dari pemeriksaan fungsi ginjal, didapatkan nilai ureum $24 \mathrm{mg} / \mathrm{dL}$ dan kreatinin $0,8 \mathrm{mg} / \mathrm{dL}$. Kadar SGOT dan SGPT mengalami peningkatan, yaitu sebesar $75 \mathrm{U} / \mathrm{I}$ dan 129 $\mathrm{U} / \mathrm{l}$, albumin 3,5 g/dL dan globulin 3,9 g/dL. Kadar LDH juga meningkat, yaitu sebesar 256 U/I. Untuk faal hemostasis, PT dan aPTT didapatkan normal, yaitu 9,7 detik dan 37,2 detik secara berurutan. Namun ditemukan peningkatan pada kadar DDimer, yaitu $1.683,48 \mathrm{ng} / \mathrm{mL}$ yang menunjukkan tingginya risiko trombosis. Hasil pemeriksaan urin dan feses dalam batas normal, sementara penanda hepatitis HBsAg dan anti HCV keduanya menunjukkan hasil nonreaktif.

Pemeriksaan ANA profile dilakukan dan didapatkan beberapa hasil yang positif, yaitu RNP/Sm (RNP/Sm) (++), Sm (Sm) (+), Ro-52 recombinant (52) (+), PCNA (PCNA) $(+)$, DsDNA (DNA) (+), Nucleosome (NUC) $(+)$, Histone $(\mathrm{HI})(++)$, Ribosomal-P-protein (RIB) (+++), dan AMA-M2 (M2) (+). Dari pemeriksaan radiografi toraks, didapatkan hasil dalam batas normal. Pasien juga menjalani pemeriksaan USG abdomen dengan hasil normal.

Berdasarkan beberapa kriteria untuk diagnosis LES, total skor pada pasien memenuhi syarat diagnosis LES. Dari 
kriteria ACR 1997, didapatkan 8 dari 11 kriteria, yaitu ruam malar, ruam diskoid, fotosensitivitas, ulkus mulut, artritis nonerosif, gangguan hematologi, gangguan imunologi, dan ANA yang positif. Sedangkan dari kriteria SLICC 2012 didapatkan 9 dari 17 kriteria, yaitu ruam lupus fotosensitivitas, ruam diskoid, ulkus oral, alopesia tanpa jaringan parut, sinovitis $\geq 2$ sendi, leukopenia, peningkatan titer ANA, dsDNA, dan AntiSm. Sementara menurut kriteria klasifikasi EULAR/ACR, didapatkan total 21 yang meliputi domain kulit, domain artritis, domain hematologik serta domain imunologi.

Untuk menilai aktivitas penyakit LES pasien, dilakukan penghitungan skor MEXSLEDAI. Dengan adanya artritis, gangguan mukokutan, kelelahan dan leukopenia, jumlah skor MEX-SLEDAl pada pasien ini didapatkan 6 yang merupakan LES derajat sedang. Pasien didiagnosis dengan LES derajat sedang, hepatitis lupus, dan High Risk VTE. Pasien kemudian diberikan terapi dengan metil prednisolon dosis 16-16-8 mg per oral, hidroksiklorokuin $200 \mathrm{mg}$ per oral satu kali sehari, Osteocal ${ }^{\mathrm{TM}} 1000 \mathrm{mg}$ satu kali sehari, serta diberikan parasetamol untuk mengatasi keluhan nyeri sendi pada pasien. Untuk risiko VTE diberikan heparin profilaksis dengan dosis 5000 IU 2 kali sehari selama 5 hari dan dilakukan bridging dengan warfarin.

Pada akhir perawatan, terdapat perbaikan pada keluhan pasien, yaitu nyeri sendi dan lesi di wajah yang berkurang. Sedangkan dari hasil pemeriksaan laboratorium juga didapatkan perbaikan kadar leukosit menjadi $5400 / \mathrm{mm}^{3}$. Sebelum pulang pasien diedukasi mengenai penyakitnya, tanda-tanda kekambuhan, efek samping obat, faktor-faktor yang harus dihindari, dan motivasi untuk kontrol rutin ke poliklinik kepada pasien.

\section{DISKUSI}

Telah dilaporkan seorang pasien laki-laki usia 21 tahun yang dirawat di Bangsal Penyakit Dalam RSUP Dr. M. Djamil Padang dengan diagnosis LES derajat sedang, hepatitis lupus dan High risk VTE. Dalam perawatan pasien menjalani serangkaian pemeriksaan untuk penegakan diagnosis tersebut.

Sebuah studi di Amerika Serikat menggambarkan manifestasi tersering pada LES, di mana diperoleh hasil manifestasi artritis sebanyak $70,8 \%$, ruam malar 49,3\%, fotosensitivitas 48,4\%, serositis 43,9\%, dan ulkus oral 41,7\%. Antibodi antinuklear (ANA) yang positif ditemukan pada 94,1\% kasus. Berdasarkan data dari negara-negara Asia Pasifik, didapatkan bahwa manifestasi klinis LES yang tersering adalah artritis nonerosif, yaitu sebanyak 48-83\%, ruam malar sebanyak 41-84\%, dan kelainan ginjal sebanyak 30-82\%. Manifestasi laboratoris dengan hasil ANA positif mencapai 93$100 \%$ dan anti dsDNA $51-86 \%{ }^{3}$

Diagnosis LES ditegakkan dari anamnesis, pemeriksaan fisik dan pemeriksaan penunjang. Pada pasien ini dari anamnesis ditemukan keluhan nyeri sendi, bercak 
merah seperti kupu-kupu yang tambah memerah jika terkena sinar matahari pada muka yang bertambah merah bila terkena cahaya matahari, stomatitis, serta rambut rontok. Dari pemeriksaan laboratorium, didapatkan leukopenia. Hasil pemeriksaan ANA profile menunjukkan RNP/Sm (RNP/Sm) (++), Sm (+), Ro-52 recombinant (52) (+), PCNA (PCNA) (+), DsDNA (DNA) $(+), \mathrm{NUC}(+)$, Histone (HI) (++), Ribosomal-Pprotein (RIB) $(+++)$, dan AMA-M2 (M2) (+) yang menunjang diagnosis LES. Menurut American College of Rheumatology (ACR), pada pasien ini ditemukan 8 kriteria, sehingga pasien ini ditegakkan dan diterapi sebagai LES. Selain itu, hasil pemeriksaan ini juga memenuhi kriteria klasifikasi SLICC 2012 dan EULAR/ACR 2018, dengan jumlah 9 dan 21 berturut-turut. Menurut Perhimpunan Reumatologi Indonesia, bila dijumpai 4 atau lebih kriteria tersebut, diagnosis LES memiliki sensitivitas $85 \%$ dan spesifisitas $95 \%$. Titer anti ds-DNA yang tinggi hampir pasti menunjukkan diagnosis LES. ${ }^{3,7}$

Lupus eritematosus sistemik pada pria merupakan hal yang jarang terjadi, di mana rasio wanita dan pria sebesar 9-14:1. Menurut Murphy et al., perbandingan kasus LES antara wanita dan pria 8-15:1. Kasus pada pria juga ditemukan lebih berat daripada wanita dengan peningkatan insiden untuk kejadian nefritis lupus, serositis, trombosis, dan kelainan kulit diskoid. Munculan gejala klinis LES pada pria bervariasi dipengaruhi berbagai faktor seperti umur dan etnis pasien. Sebagai contoh, pada ras Afro-Amerika munculan klinis berupa gangguan renal, discoid lupus, dan fotosensitivitas, tapi pada ras Kaukasia-Hispanik munculan klinis yang dominan adalah artritis. ${ }^{11,12}$

Peningkatan frekuensi LES pada wanita diyakini berhubungan dengan efek hormon seks endogen. Hormon seks ini dapat berinteraksi dengan sistem imun, yaitu sel $B$ dan sel $T$, sel dendritik, dan sitokin. Hormon seks pada wanita, estrogen, dapat meningkatkan reaktivitas autoimun dan menimbulkan gangguan sistem imun, sehingga menyebabkan terjadinya LES. Sedangkan hormon pria, androgen, terbukti berperan sebagai agen protektif. ${ }^{13}$

Pada pasien ini ditemukan peningkatan enzim hati tanpa hepatomegali dan ikterik. Organ hati bukan merupakan organ utama dalam patogenesis LES, tapi angka kejadian gangguan fungsi hati atau peningkatan enzim hati dalam kasus LES berkisar 19$60 \%$. Sejauh ini belum jelas korelasi antara aktivitas LES dengan kejadian gangguan hati pada pasien LES. Komplikasi hati yang berkaitan dengan LES di antaranya hepatitis lupus (SLE-related hepatitis), hepatitis autoimun dan lain - lain. Untuk membedakan penyebab gangguan hati pada pasien LES cukup sulit karena penggunan obat - obatan imunosupresan. Hepatitis lupus merupakan gangguan hati yang terkait LES di mana adanya fluktuasi kadar alanin transaminase yang konsisten terhadap aktivitas LES. Hepatitis lupus dilaporkan suatu keadaan dengan derajat progresif yang rendah untuk menjadi penyakit hati tahap akhir. ${ }^{14,15}$ Zheng et al. melaporkan hepatitis lupus lebih sering 
pada LES yang aktif dibandingkan yang tidak. Hepatitis lupus dilaporkan 3-9 \% pasien dengan LES dan ditemukan serum anti-Ribosomal $\mathrm{P}$ yang cukup tinggi pada pasien. ${ }^{16}$ Pada pasien ini didapatkan nilai anti-ribosomal $P$ yang $(+++)$ dan tidak terdapat riwayat penggunaan obat-obat bersifat hepatotoksik. Selain itu pemeriksaan darah menunjukkan marke hepatitis negatif dan dari pemeriksaan USG abdomen didapatkan hasil yang normal.

Leukopenia yang terjadi pada pasien menunjang untuk diagnosis LES pada pasien. Kriteria ARA untuk diagnosis LES pada sistem hematologi salah satunya adalah

leukopenia

$<4000 / \mathrm{mm}^{3}$. Leukopenia pada pasien LES terjadi sekitar $20-81 \%$. Neutrofil dan atau limfosit di sirkulasi dapat menurun akibat beberapa sebab. Limfosit $T$ dan limfosit $B$ keduanya menurun, akan tetapi sel NK akan meningkat. Penurunan ekspresi protein komplemen CD 55 dan CD 59 ditemukan pada pasien LES dengan leukopenia. Keadaan leukopenia pada pasien LES bisa berupa onset akut dan berat (perdarahan) dan keadaan ini biasanya sangat berespon dengan pemberian kortikosteroid. Hal ini terbukti setelah pemberian steroid terjadi perbaikan terhadap kadar leukosit pasien. Imunosupresan seperti azathioprine atau siklofosfamid berpotensi bisa memperburuk kondisi leukopenia pada pasien LES melalui aktivitas penekanan sumsum tulang. ${ }^{17,18}$

Keadaan hiperkoagulasi pada pasien LES bukan termasuk ke dalam kriteria diagnostik dan mempunyai banyak mekanisme, di antaranya disregulasi sistem imun yang berat terhadap inflamasi sistemik dan disfungsi endotel. Kondisi ini terjadi pada $>10 \%$ pasien LES dan meningkat $>50 \%$ pada pasien dengan risiko tinggi. Dalam studi kohort selama 10 tahun pada pasien LES, penyebab utama kematian nomor dua adalah trombosis sekitar 26,5\% dan mendominasi pada 5 tahun kedua saat follow up. ${ }^{19,20}$ Insiden trombosis meningkat pada tahun pertama, di mana utamanya disebabkan oleh aktivitas penyakit yang tinggi atau aktivitas kompleks imun, antibodi sitotoksik yang tinggi. Pada pasien lupus terjadi inflamasi yang dapat meningkatkan faktor prokoagulan. Faktor lain yang berhubungan dengan hiperkoagulasi adalah adanya hiperhomosisteinemia, peningkatan Plasminogen Activator Inhibitor-1 (PAl-1) yang akan menurunkan aktivitas fibrinolitik, dan penurunan faktor antikoagulan seperti protein $\mathrm{C}$, protein S, dan tissue Plasminogen Activator (tPA) yang bekerja mengaktifkan sistem fibrinolitik. Selain itu, pada pasien LES sering didapatkan antibodi antifosfolipid yang dapat menyebabkan terjadinya trombosis berulang pada pasien LES. ${ }^{21}$ Pada pasien ini didapatkan D-Dimer meningkat yang menunjukkan terjadinya hiperkoagulasi pada pasien. Penatalaksanaan pada pasien inti diberikan antikoagulan heparin selama 5 hari yang dilanjutkan bridging dengan warfarin. Dalam follow up, pasien LES yang mendapatkan antikoagulan dipantau dengan target INR 2-3 kali nilai normal. 
Untuk menilai aktivitas penyakit, dilakukan penilaian skor MEX-SLEDAI. Pada pasien didapatkan skor 6 yang merupakan LES derajat sedang.

Untuk follow up pasien dianjurkan untuk kontrol secara rutin sehingga perjalanan penyakit dan efek samping pengobatan pada pasien dapat diawasi. Penurunan dosis kortikosteroid harus dilakukan secara hati-hati tergantung dari aktivitas penyakit, dosis, dan lama terapi, serta respon klinis. Kortikosteroid umumnya diturunkan hingga mencapai dosis minimal yang masih efektif dan selanjutnya diusahakan untuk menghentikan kortikosteroid. Penurunan kortikosteroid dapat dimulai setelah 1-2 minggu pemberian (dengan respon positif) atau jika agen sitotoksik telah ditambahkan ke dalam regimen terapi. ${ }^{3,22}$ Selain itu, juga perlu dilakukan pemeriksaan darah rutin dan kimia darah setiap 3 bulan dan pemeriksaan anti dsDNA setiap 3-6 bulan sekali. $^{3}$

Selain melakukan pemantauan rutin, pasien LES juga harus diedukasi mengenai perjalanan penyakitnya, serta memotivasi pola hidup sehat. Pola hidup sehat yang ditekankan meliputi aktivitas fisik dan olahraga setelah aktivitas penyakit mengalami perbaikan, yang dapat mengurangi risiko kardiovaskuler pada pasien LES. Nutrisi yang optimal juga harus diperhatikan yang meliputi kalori, protein, lemak tidak jenuh, dan mikronutrien. Hal penting lainnya adalah menghindari merokok ataupun paparan asap rokok, serta menghindari paparan sinar matahari berlebih. $^{3}$

\section{KESIMPULAN}

Lupus eritematosus sistemik (LSE) merupakan penyakit autoimun yang menyerang berbagai sistem dalam tubuh dan memiliki manifestasi yang beragam. Prevalensi LES pada pria lebih jarang terjadi dibandingkan pada wanita, sehingga membutuhkan ketelitian dalam mendiagnosis lebih cepat dan tepat. Pasien pria dengan LES umumnya memiliki manifestasi yang lebih beragam dan derajat penyakit yang lebih berat dibandingkan pasien wanita.

\section{DUKUNGAN FINANSIAL}

Penulis tidak memiliki dukungan finansial dalam pembuatan laporan kasus ini.

\section{UCAPAN TERIMA KASIH}

Penulis mengucapkan terimakasih kepada pihak yang telah berpartisipasi membantu mengerjakan laporan kasus ini hingga selesai.

\section{KONFLIK KEPENTINGAN}

Penulis tidak memiliki konflik kepentingan dalam penelitian ini. 


\section{DAFTAR PUSTAKA}

1. Abdulrahman MA, Afifi N, El-Ashry M. Neutrophil/lymphocyte and platelet/lymphocyte ratios are useful predictors comparable to serum IL6 for disease activity and damage in naive and relapsing patients with lupus nephritis. The Egyptian Rheumatologist. 2020 Apr;42(2):107-12.

2. Tsai CY, Hsieh SC, Lu CS, Wu TH, Liao HT, Wu CH, et al. Cross-talk between mitochondrial dysfunction-provoked oxidative stress and aberrant noncoding rna expression in the pathogenesis and pathophysiology of SLE. Int J Mol Sci [Internet]. 2019 Jan;20(20):1-18. Available from: https://www.mdpi.com/1422-0067/20/20/5183 DOI: 10.3390/ijms20205183

3. Perhimpunan Reumatologi Indonesia. Diagnosis dan Pengelolaan Lupus Eritematosus Sistemik [Internet]. Indonesia: Perhimpunan Reumatologi Indonesia; 2019. Available from: http://reumatologi.or.id/reurek/download/55

4. Suarjana NI. Imunopatogenesis Lupus Eritematosus Sistemik. In: Setiati S. Buku Ajar Ilmu Penyakit Dalam Edisi VI. Jakarta: Interna Publishing; 2015. p. 3331-45.

5. Lim SS, Drenkard C. The Epidemiology of Lupus. In: Wallace DJ \& Hahn BH, editors. Dubois' Lupus Erythematosus and Related Syndromes. 9th ed. Edinburgh: Elsevier; 2018. p. 23-41.

6. Hahn BH. Systemic Lupus Erythematosus. In: Fauci AS, editor. Harrison's Rheumatology. 4th ed. New York: McGraw Hill Education; 2016. p. 70-85.

7. Yazdany J, Dall'Era M. Definition and Classification of Lupus and Lupus-Related Disorders. In: Wallace DJ \& Hahn BH, editors. Dubois' Lupus Erythematosus and Related Syndromes. 9th ed. Edinburgh: Elsevier; 2018. p. 15-20.

8. Kasjmir YI, Handono K, Wijaya LK, Hamijoyo L, Albar Z, Kalim H, et al. Diagnosis dan Pengelolaan Lupus Eritematosus Sistemik. In: Setiati S. Buku Ajar Ilmu Penyakit Dalam Edisi VI. Jakarta: Interna Publishing; 2015. p. 3360-77.

9. Murphy $\mathrm{G}$, Isenberg D. Effect of gender on clinical presentation in systemic lupus erythematosus. Rheumatology. 2013 Dec;52(12):2108-15.

10. Shaharir SS, Kadir WA, Nordin F, Bakar FA, Ting M, Jamil A, et al. Systemic lupus erythematosus among male patients in Malaysia: how are we different from other geographical regions? Lupus. 2019;28(1):137-44.

11. Murphy G, Isenberg D. Effect of gender on clinical presentation in systemic lupus erythematosus. Rheumatology. 2013;52(12):2108-15.

12. Rastin M, Mahmoudi M, Sahebari M, Tsabasi N. Clinical \& immunological characteristics in systemic lupus erythematosus patients. Indian J Med Res. 2017;146(2):224-9.

13. Christou EAA, Banos A, Kosmara D, Bertsias GK, Boumpas DT. Sexual dismorphism in SLE: above and beyond sex hormones. Lupus. 2019;28(1): 3-10.

14. Adiga A, Nugent K. Lupus hepatitis and autoimmune hepatitis (lupoid hepatitis). Am J Med Sci. 2017;353(4):329-35.

15. Weinberg S, Sequeira W, Jolly M. Gastrointestinal and Hepatic Systems. In: Wallace DJ, Hahn BH, editors. Dubois' Lupus Erythematosus and Related Syndromes. 9th ed. Edinburgh: Elsevier; 2018. p. 457-68.

16. Shizuma T. Liver complications associated with systemic lupus erythematosus. Rheumatology (Sunnyvale). 2015;5(1):1-5. 
17. Bashal F. Hematological disorders in patients with systemic lupus erythematosus. Open Rheumatol J.2013; 7: 87-95.

18. Karpouzas, GA. Hematologic and Lymphoid Abnormalities in SLE. In: Wallace DJ \& Hahn BH, editors. Dubois' Lupus Erythematosus and Related Syndromes. 9th ed. Edinburgh: Elsevier; 2018. p. 473-83.

19. Bazzan M, Vaccarino A, Marletto F. Systemic lupus erythematosus and thrombosis. Thromb J [Internet]. 2015;13(16):1-10. Available from: https://link.springer.com/content/pdf/10.1186/s12959-015-0043-3.pdf DOI: 10.1186/s12959015-0043-3

20. Kishore S, Jatwani S, Malhotra B, Lirette ST, Mittal V, Majithia V. Systemic lupus erythematosus is associated with a high risk of venous thromboembolism in hospitalized patients leading to poor outcomes and a higher cost: results from nationwide inpatient sample database 2003-2011. ACR Open Rheumatol. 2019;1(3):194-200.

21. Giles I, Cohen H, loannou Y. Pathogenesis of Antiphospholipid Antibody Syndrome. In: Wallace DJ \& Hahn BH, editors. Dubois' Lupus Erythematosus and Related Syndromes. 9th ed. Edinburgh: Elsevier; 2018. p. 324-334.

22. Nataraja C, Morand E. Systemic Glucocorticoid Therapy for SLE. In: Wallace DJ \& Hahn BH, editors. Dubois' Lupus Erythematosus and Related Syndromes. 9th ed. Edinburgh: Elsevier; 2018. p. 661667. 